\title{
Sites and Senses
}

\section{Mapping Palestinian Territories in Mona Hatoum's Sculpture Present Tense}

\author{
Anneke Schulenberg
}

In April 1996, Mona Hatoum, a British artist of Palestinian origin, installed a work entitled Present Tense at the Anadiel Gallery in East Jerusalem, an area annexed by Israel in 1967 (Figs 1.1-1.2). ${ }^{1}$ On the floor of the gallery, Hatoum laid 2400 pieces of soap in a rectangular shape. The soap was Nablus soap, a traditional Palestinian product made of olive oil. Hatoum pressed tiny red glass beads in curved lines into the soap (Fig. 1.2). At first sight, the lines seem to make up abstract forms, but in fact they depict part of the occupied Palestinian territories that, as determined by the 1993 Oslo Accords, Israel should have handed back to the Palestinian authorities. Hatoum came across a map of these territories on the first day of her visit to Jerusalem. In Present Tense, she omitted the outlines of the map of Israel, only drawing the Palestinian territories: fragmented parcels of land, scattered across Israel, resembling an archipelago.

Present Tense was originally a site-specific sculpture as the work was made specifically for that exhibition in Jerusalem and was an immediate response to the site. By inscribing the map of the Oslo Accords on a local traditional product, Hatoum investigated the political, social and cultural dynamics at play within the Israeli-Palestinian conflict. Drawing only the Palestinian territories in Israel on the soap, Hatoum focused on the Palestinian situation within the conflict. The context of the city of Jerusalem affected the meaning of the artwork, enhancing the political dimension. Jerusalem was and remains the core issue in the Israeli-Palestinian conflict as it is claimed by both parties to be the capital of their states. Yet since the exhibition in Jerusalem, Present Tense has been displayed in several solo and group exhibitions, and was even acquired by

1 The Anadiel Gallery is now called the Al-Ma'ham Foundation, and its aim is 'to promote, instigate, disseminate and make art in Palestine': “Al-Ma'hal Historical Background,” Al-Ma'hal. Foundation for Contemporary Art, http://www.almamalfoundation.org/aboutus.php (accessed on 28 June 2012).

(C) ANNEKE SCHULENBERG, 2014 | DOI 10.1163/9789004270855_003

This is an open access chapter distributed under the terms of the Creative Commons AttributionNoncommercial 3.o Unported (CC-BY-NC 3.0) License. 


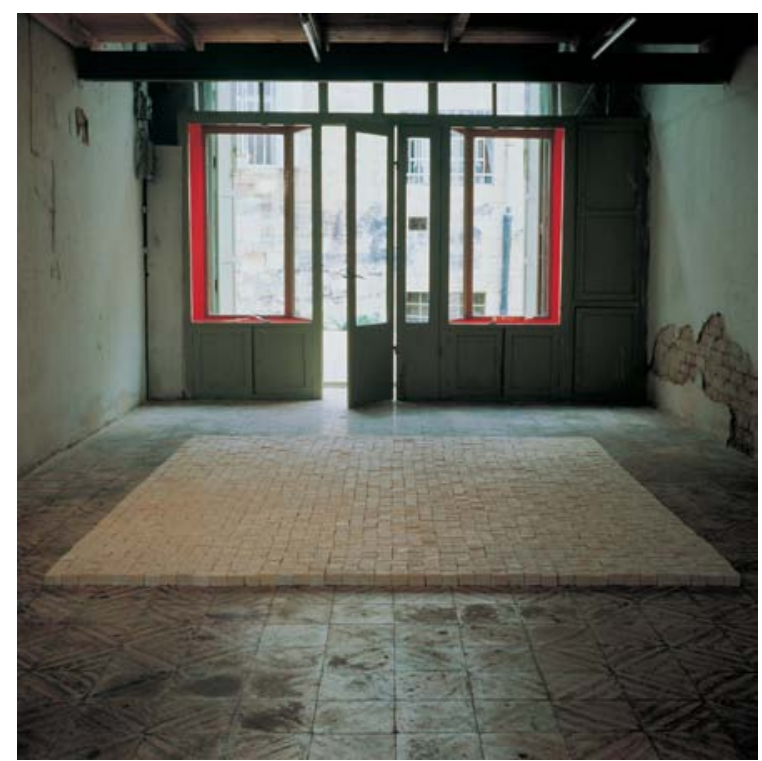

FIGURE 1.1 Mona Hatoum, Present Tense, 1996, soap and glass beads, $4.5 \times 241 \times 299 \mathrm{~cm}$, installation at Anadiel Gallery, Jerusalem. COURTESY WHITE CUBE AND ANADIEL GALLERY, JERUSALEM.

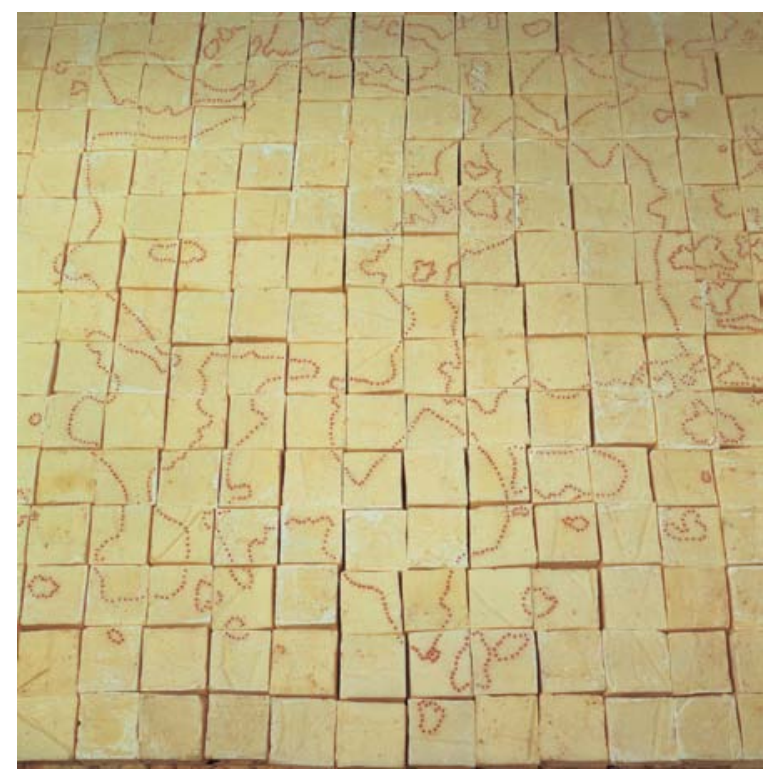

FIGURE 1.2 Mona Hatoum, Present Tense (detail), 1996, soap and glass beads, $4.5 \times 241 \times 299 \mathrm{~cm}$, installation at Anadiel Gallery, Jerusalem. COURTESY WHITE CUBE AND ANADIEL GALLERY, JERUSALEM. 
Tate in 2013. The important relation between the work and its original site is now broken, which affects the meaning of the work.

With Present Tense, Hatoum not only explored the implications of the map for the Palestinians, but also set up a relationship between the work and the viewer. She constructs this relationship by adopting the aesthetic language of Minimal Art, more specifically its strategies to establish a relationship between the viewer and the artwork, in her case by activating the viewer's olfactory organ through the smell of soap. Through this relationship, an interplay takes place between the political content of the work, the site and the viewer. Although the exhibition at the Anadiel Gallery included several of Hatoum's works, this contribution focuses on how Hatoum, in her site-specific sculpture Present Tense - as installed in Jerusalem - sets up a physical encounter between artwork and viewer by stimulating the senses, in order to examine the socio-political implications for the Palestinians of the map of the Oslo Accords. I will end with a discussion of the consequences for the meaning of the work of reinstalling it in other places.

\section{Mapping Palestinian Territories}

When Hatoum, the daughter of Palestinian refugees, went to Jerusalem for her solo exhibition at the Anadiel Gallery, it was her first visit to the former homeland of her parents. In an interview with Michael Archer, Hatoum revealed how she felt about working in Jerusalem: 'Going to Jerusalem was a very significant journey for me, because I had never been there. [...] Jack Persekian, who has this little gallery in East Jerusalem, and I had been discussing the possibility of doing the exhibition there for over two years. I kept postponing it because emotionally it's a very heavy thing ....'2

The visit to Jerusalem was of personal importance for Hatoum. She was born in $195^{2}$ in Beirut, Lebanon, but her family is originally from Haifa. When the Jewish militants bombed Haifa in 1948, the family fled to Beirut. While Hatoum was visiting London in 1975, the Lebanese civil war broke out. Expecting the conflict to last for a few days, maybe weeks, she planned to return to Beirut. As the problems lasted longer than she expected and the Beirut airport was closed for nine months, she was forced to stay in London. Hatoum decided to attend art school, first the Byam Shaw School of Art (1975-79), followed by the Slade School of Art (1979-81). ${ }^{3}$ After she finished art school, Hatoum

2 Hatoum interviewed by: Archer 1997, p. 26.

3 Brett 1997, pp. 34-35. 
remained in London, where she currently still lives and works, although she has also had a studio in Berlin for several years.

When Hatoum finally decided to exhibit in Jerusalem, it seemed almost inevitable that the context of the city would play a role in the exhibition, not only because of her Palestinian background, but also because she often creates artworks in response to the context of the location of an exhibition. Before going to Jerusalem, Hatoum already had ideas for the gallery show, but never executed them when she arrived in the city: 'The ideas I had proposed beforehand seemed to be about turning the gallery into a hostile environment, but the environment outside was already so hostile that people hardly needed reminding. ${ }^{4}$ As mentioned earlier, on her first day in Jerusalem, Hatoum stumbled upon a map of the Oslo agreement. After some consideration she decided to make a sculpture based on it: 'When I first came across [the map], I had no intention of using it, but a week later I decided I would like to do something with this local soap made from pure olive oil, and the work came together. ${ }^{5}$ The hostility of the environment of Jerusalem also seems to have affected Hatoum's choice of the red beads: 'Originally I was going to draw the outline of the map by pushing nails into the soap, but it looked quite aggressive and sad. I ended up using little glass beads which I pressed into the soap. ${ }^{6}$

From ancient times onward, map-making has been tied to conquest. ${ }^{7}$ Maps are often used to affirm territorial claims, as is the case with the map from the Oslo Accords. In 1993, an attempt was made to resolve the ongoing conflict between Palestinians and Israelis. The government of Israel and the Palestine Liberation Organization (PLO) signed, after years of negotiations, the Oslo Accords, also called Oslo I, or, officially, the Declaration of Principles on Interim Self-Government Arrangements. In this agreement, the two parties decided that the Israeli army would withdraw from some parts of the West Bank and

$4 \quad$ Hatoum interviewed by: Archer 1997, p. 26. According to Gannit Ankori, Hatoum's visit to her homeland, or her going back 'home', as well as the 'cosy' atmosphere of the gallery, eventually inspired Hatoum to turn the space into 'a symbolic home'. He claims that her use of the traditional soap alludes to the bathroom, arguing that other works in the exhibition can also be related to specific home spaces. In the sculptures No Way and No Way II, Hatoum placed bolts in the holes of two kitchen utensils - a colander and a strainer turning them into strange objects normally kept in kitchens. On the second floor, Hatoum displayed a metal bed without a mattress called Lili (Stay) Put, as a reference to a bedroom. The bed was standing in the middle of the room, tied to the floor with transparent nylon threads, evoking, according to Ankori, 'the conflict between displacement and rootedness'. See: Ankori 2006, pp. 141-43.

5 Hatoum interviewed by: Archer 1997, pp. 26-27.

6 Hatoum interviewed by: Archer 1997, p. 27.

$7 \quad$ Black 1997, p. 9. 
the Gaza Strip. Furthermore, a provisional Palestinian self-governance would be established, and Israel and Palestine would publicly recognize each other. A new series of negotiations, however, would have to be set up on issues such as the exact borders between Israeli and Palestinian territories, return of Palestinian refugees, Jewish settlements in the Occupied Territories, and the biggest problem of all, the future of Jerusalem. ${ }^{8}$

Present Tense not only examines a political map, but was also created especially for the exhibition in Jerusalem, and the context of the city frames the meaning of the work. Jerusalem has a long and complex history, but for the sake of this contribution, only the relevant events after 1948 will be expounded upon. The Anadiel Gallery, in which Present Tense was exhibited, was located in East Jerusalem. In 1948, East Jerusalem was occupied by Jordan, while Israel had captured West Jerusalem. One year before, however, in 1947, the General Assembly of the United Nations had agreed to make an international zone, including Jerusalem, that would be governed by a U.N. trusteeship council. Before this plan could be made operable, Jerusalem had already been divided between Israel and Jordan. Israel then claimed Jerusalem as its capital in 1950, going on to conquer East Jerusalem in 1967. According to the international community, Jerusalem's situation remains undecided and, as such, it does not recognize Israel's claim of Jerusalem as its capital. The capture of East Jerusalem in 1967 is also seen by the international community as illegal, and it treats East Jerusalem as Palestinian territory under military occupation by Israel. The Palestinians claim East Jerusalem as the capital of their future Palestinian state. ${ }^{9}$ Present Tense was thus created in a highly contested area in the IsraeliPalestinian conflict.

Moreover, Present Tense was created in April 1996, only months after Israeli prime minister Yitzhak Rabin was murdered. A few months before this murder, on 24 September 1995, the second part of the Oslo Accords, Oslo II, had been signed by Israel and the PLo. This second agreement gave the Palestinians selfgovernance in Bethlehem, Hebron, Jenin, Nablus, Qalqilya, Ramallah, Tulkarm, as well as in approximately 450 villages. On 28 September, Oslo II was ratified by Rabin and PLo chairman Yasser Arafat. Just over five weeks later, on 4 November 1995, Rabin was murdered by an Israeli opponent of the Oslo Accords. After this incident, the peace process began to fall apart and violent attacks by Islamic fundamentalists of Hamas led to a halt to negotiations with the Palestinians. ${ }^{10}$ Although Present Tense does not refer to these political events, they

\footnotetext{
8 Fischback 2000[a], p. 284.

9 Fischbach 200o[b], pp. 213-16.

$10 \quad$ Montefiore 2011, p. 507.
} 
are likely to have framed the viewer's experience of the work in the East Jerusalem gallery at that time.

The map which was drawn as a result of the 1993 Oslo Accords to indicate the future Palestinian territories in Israel, was the point of departure for Hatoum's work. This map is a reflection of political ideas and serves military goals of controlling the territorial divisions, something Hatoum is well aware of: '[...] [I]t was a map about dividing and controlling the area. At the first sign of trouble, Israel practises the policy of 'closure': they close all the passages between the areas so that the Arabs are completely isolated and paralyzed'."1 The division of the territories by the Oslo Accords has served as a form of surveillance of the Palestinians, the map representing power relations.

The topic of surveillance and control of human beings has been of interest to Hatoum ever since as a student she read the book Discipline and Punish: the Birth of the Prison by the French philosopher Michel Foucault. ${ }^{12}$ In this book Foucault argues that the disciplinary techniques used in prisons starting in the middle of the eighteenth century are a means of controlling people. One of the techniques Foucault describes is hierarchical observation. People can be made to behave in certain ways by merely observing them. Several architectural structures, such as watchtowers, are designed for observation and command over people, but Foucault was especially interested in Jeremy Bentham's panopticon. The panopticon is a cylindrical construction with a small tower in the middle of a huge cupula. All the cells of the inmates are located around this tower against the wall of the cylinder. From the central tower, a guard can monitor each cell. The key to disciplining the prisoners is to make them believe they are under constant observation, even if they are not. Thus, inmates are controlled through surveillance, not only as a result of physical constraints. Foucault argued that through this threat of observation of the bodies that need to be controlled, institutions like prisons have moulded bodies into the correct form, creating so-called 'docile bodies'. Docile bodies were ideal in a modern industrial society as they would also function in other disciplinary institutions, such as factories, military regiments, and schools. ${ }^{13}$

Hatoum has made a number of artworks that deal with issues of control and surveillance, mainly in relation to institutional and architectural structures, for example Light Sentence (1992) (Fig. 1.3). For this work, Hatoum piled up wire mesh lockers and placed them in the middle of a dark room. Some of the locker doors are open. The vertical piles of lockers are connected to each other to

\footnotetext{
11 Hatoum interviewed by: Archer 1997, p. 27.

12 Pieters 1997, s.p.

13 Foucault 1979, pp. 135-41, 170-77, and 195-228.
} 


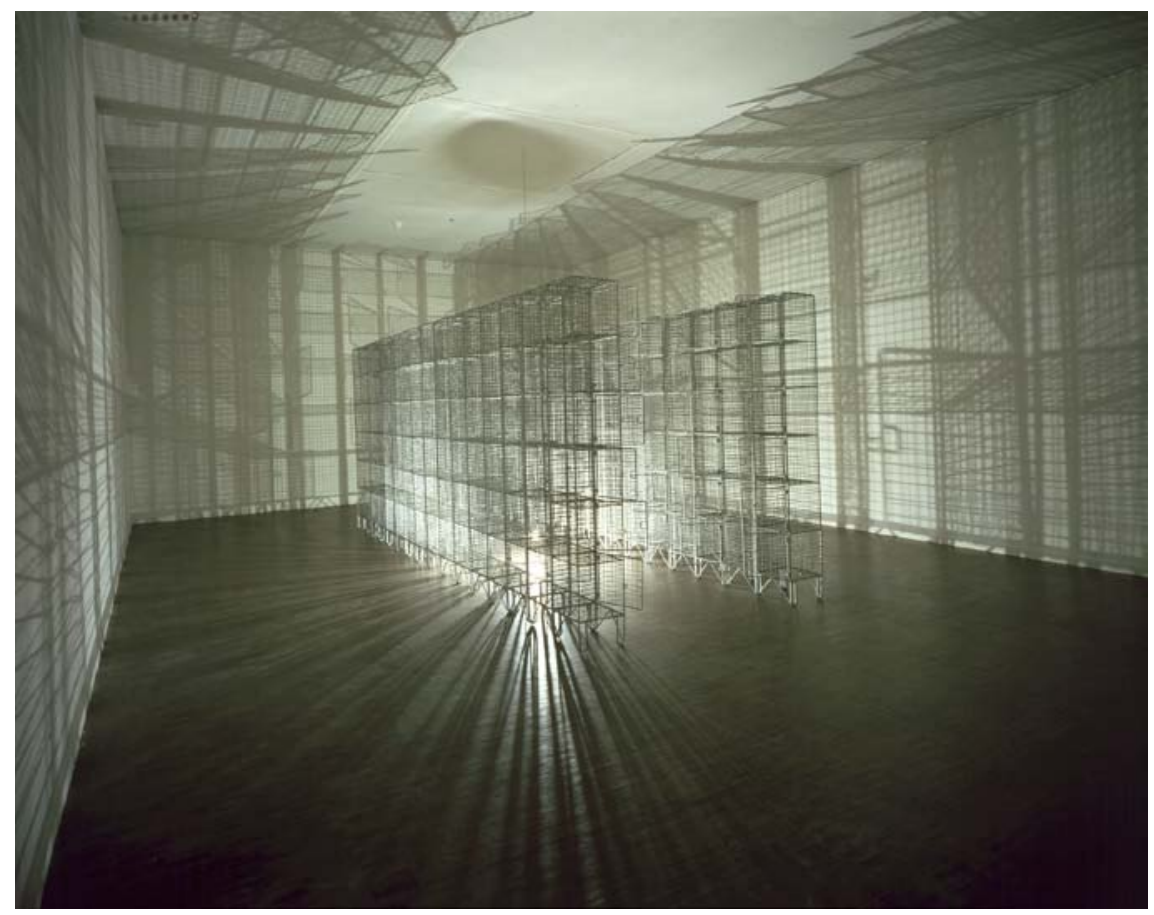

FIGURE 1.3

Mona Hatoum, Light Sentence, 1992, wire mesh lockers, slow-moving motorized light bulb, $198 \times 185 \times 490 \mathrm{~cm}$. PHOTO: PHILIPPE MIGEAT. COURTESY CENTRE POMPIDOU, PARIS.

form a U-shape. In the middle of the U-shape a light bulb hangs from the ceiling. This light bulb slowly moves from the ceiling to the floor, touches the floor, and after slightly toppling over, slowly rises again. The light from the bulb falls on the lockers, casting shadows on the walls of the room. When the light bulb reaches the floor, the shadows begin to tremble. Visitors who enter the installation see their own shadows projected onto the wall, making them part of the installation, and are burdened with feelings of unease, or as Hatoum described it:

[...] [T] he movement of the light bulb causes the shadows of the wire mesh lockers to be in perpetual motion, which creates a very unsettling feeling. When you enter the space you have the impression that the whole room is swaying and you have the disturbing feeling that the ground is shifting under your feet. This is an environment in constant flux - no 
single point of view, no solid frame of reference. There is a sense of instability and restlessness in the work. ${ }^{14}$

With the title Light Sentence, Hatoum steers the viewer's interpretation towards ideas of confinement or imprisonment. The lockers, however, are perhaps also an allusion to other institutional structures, like schools or factories, where people can put their personal belongings in lockers before going to class or to work. As Foucault indicated, these institutions also discipline people, since they set norms - either through examination of students or job descriptions that determine their behaviour - which people have to adjust to. For Hatoum, Light Sentence refers to all instances where the built environment is designed to restrict personal freedom:

[...] I have now spent half of my life living in the West, so when I speak of works like Light Sentence, [...] as making a reference to some kind of institutional violence, I am speaking of encountering architectural and institutional structures in Western urban environments that are about the regimentation of individuals, fixing them in space and putting them under surveillance. ${ }^{15}$

Although Present Tense does not directly refer to structures of control, the divisions of territories in the Oslo Accords also fixed people to spaces in order to put them under surveillance. The map of the Oslo Accords shows how Palestinians were to be confined in small areas. Hatoum also refers to these restrictions: '[...] [T] he saddest thing in Jerusalem was the policy of 'closure' that restricted movement for the Arabs'. ${ }^{16}$ Also, the Palestinian Authority took over the task of policing the Palestinian population inside the territories, and quickly set up police and security forces. Israel, however, maintained control over the borders, airspace, labor, water and natural resources of the occupied territories. Israel also controlled the registration of the population, possessing the

\footnotetext{
14 Hatoum interviewed by: Antoni 2002, p. 117.

15 Hatoum interviewed by: Antoni 2002, pp. 117-19. Although Hatoum specifically relates institutional violence to Western urban environments, institutionalization is not a typical Western phenomenon. Hatoum perhaps relates institutionalization to Western environments, because - she has stated - it was in London that she for the first time became aware of such an institution: 'The Slade [School of Fine Art] was my first encounter with a large institution, and the impersonal, bureaucratic machinery that constitutes the 'institution' was totally foreign to me. I was so much at odds with that environment that I started to examine the reasons why'. Hatoum interviewed by: Archer 1997, p. 10.

Hatoum interviewed by: Archer 1997, pp. 27-28.
} 
power to grant Palestinians residency, to change their residency status (for instance from Gaza to the West Bank), and to issue identity cards. ${ }^{17}$ Palestinians were also confronted with checkpoints, curfews, and road blocks that were used by the Israelis to restrict the movement of the Palestinians. Thus, Palestinians were not only confined to small areas, but 'the institutionalized system of checkpoints, curfews, and closures introduced by Oslo led to ever-greater immobilization and paralysis .... ${ }^{18}$

In Present Tense, Hatoum not only explores the confinement of people to restricted areas using military presence, but also utters a hope that the situation will change. The title Present Tense is based on the grammatical term for the inflection of verbs to locate a situation in the present time, but it can also refer to a tense situation in the present. Hatoum has explained the title as follows: 'The piece is called Present Tense; it's about the situation as it was then'19 Hatoum's reference in this quote to a specific situation at a specific time already hints at the fact that the territorial divisions are subject to change due to political conflicts. Hatoum has stated about Present Tense, in reference to the transient nature of soap, that 'it holds the promise [the soap] will dissolve one day and with it all these ridiculous borders'. ${ }^{20}$ Thus, the fragility and instability of the borders as well as Hatoum's hope that the borders will dissolve is reflected in the nature of the material.

Present Tense was the first of Hatoum's works to deal with the issue of mapping and change. Many followed afterwards. According to Hatoum, maps 'give [...] the allusion of a stable, measurable space. [My] works are more about mappings of precarious space with unstable boundaries and a shaky geography'. ${ }^{21}$ Three years after Present Tense, Hatoum created another floor piece, called Map (1999) (Fig. 1.4). On the floor of a museum, Hatoum laid out the continents of the world with glass marbles. In contrast to Present Tense, in Map no political borders of the nations on the continents are visible; only the outlines of the continents can be seen. The map is, however, fragile, because when viewers enter the room, their steps make the floor vibrate and the glass marbles roll out of place. Viewers can slip over the dispersed glass balls, expe-

$17 \quad$ Makdisi 2008, pp. 84-85.

18 Makdisi 2008, p. 85 .

19 Hatoum interviewed by: Archer 1997, p. 27. This statement by Hatoum is not completely correct. The 1993 Oslo Accords have never been fully executed as not all of the occupied territories were returned to the Palestinian Authority by Israel.

20 Lecture by Hatoum: Mona Hatoum: Mappings, Vimeo video, 24:03 min., posted by Serpentine Gallery, 2011, http://vimeo.com/24541176 (accessed on 7 November 2012).

21 Lecture by Hatoum: Mona Hatoum: Mappings, Vimeo video, 24:03 min., posted by Serpentine Gallery, 2011, http://vimeo.com/24541176 (accessed on 7 November 2012). 


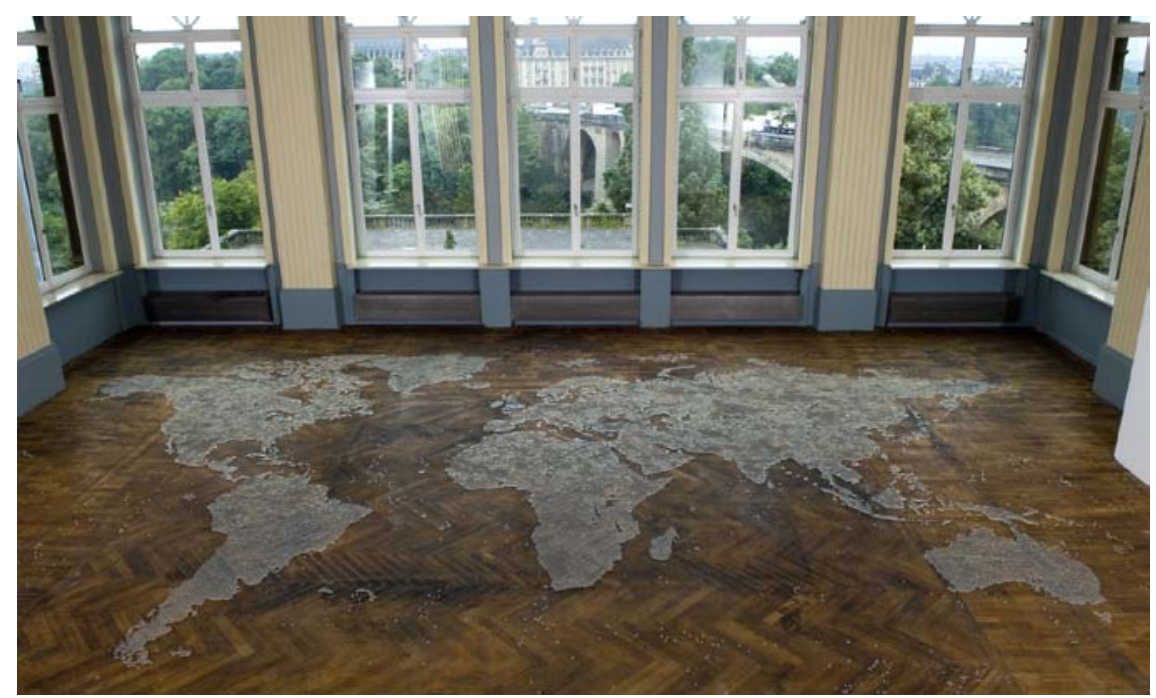

FIGURE 1.4 Mona Hatoum, Map, 1999, 14 mm clear glass marbles, installation dimensions variable. PHOTO: CHRISTIAN MOSAR. COURTESY CASINO LUXEMBOURG.

riencing the ground they walk on as unstable. Since in this work the borders are geographical rather than political, Hatoum destabilizes the surface which viewers walk upon to 'expand the idea of a shaky ground to the entire earth'. ${ }^{22}$ Showing only geographical borders, Map is less politically charged than Present Tense.

\section{Symbolic Soap of the Homeland}

For Present Tense, Hatoum used a local material that is emotionally charged for Palestinians, traditional Palestinian Nablus soap. This soap is made in Nablus, a city north of Jerusalem, out of virgin olive oil, water and a sodium compound. The centuries-old production method takes several weeks. It is said that Palestinian women were already making the soap for household purposes more than one thousand years ago. The major soap industry in the city came into existence in the tenth century, and the soap was exported across the Arab world and Europe. The industry was at its height at the end of the nineteenth century with nearly 40 factories in existence. In the twentieth century, many

22 Lecture by Hatoum: Mona Hatoum: Mappings, Vimeo video, 24:03 min., posted by Serpentine Gallery, 2011, http://vimeo.com/24541176 (accessed on 7 November 2012). 
factories were destroyed through several natural disasters, such as the earthquake in 1927, and again after Israeli military invasions which began in 2000 at the start of the Second Intifada. Currently, only two factories remain active. ${ }^{23}$ The factory that produced 'Al-Jamal' soap, the brand Hatoum used, was destroyed by Israeli forces in 2002. ${ }^{24}$

Nablus soap is thus inextricably connected to Palestinian cultural history and identity. Using this material for a sculpture in Jerusalem has political, cultural and emotional implications. For Hatoum, the soap functioned as a 'symbol of resistance. ${ }^{25}$ This symbolism might be interpreted as a resistance against oppression of Palestinians in general, but in relation to the map of the Oslo Accords imprinted on the soap, it is more a symbol of resistance against the absurdity of the borders determined by the agreement.

The soap not only functions as a symbolic sign with political connotations, but it has an additional, perhaps even more powerful, effect as the smell of the soap triggers recollection. In his book Swann's Way, Remembrance of Things Past (1913), Marcel Proust described how penetrating smells can be, as did Patrick Süskind in his novel Perfume: The Story of a Murderer (1985). Although in Süskind's novel, the main character Grenouille has extraordinary power to discern odours, which is of no importance in relation to Hatoum's work, the fragment given below does show how a smell can produce a bodily response and how it can be relived at a later time:

Grenouille sat on the logs, his legs outstretched and his back leaned against the wall of the shed. He had closed his eyes and did not stir. He saw nothing, he heard nothing, he felt nothing. He only smelled the aroma of the wood rising up around him to be captured under the bonnet of the eaves. He drank in the aroma, he drowned in it, impregnating himself through his innermost pores, until he became wood himself; he lay on the cord of wood like a wooden puppet, like Pinocchio, as if dead, until after a long while, perhaps a half hour or more, he gagged up the word "wood." He vomited the word up, as if he were filled with wood to his ears, as if buried in wood to his neck, as if his stomach, his gorge, his

\footnotetext{
23 'Nablus' olive oil soap: a Palestinian tradition lives on', Institute for Middle East Understanding (IMEU), http://imeu.net/news/articleoo8132.shtml (accessed on 7 September 2012).

24 Mansoor 2010, p. 55 n. 18; 'Mona Hatoum', Al-Ma'hal. Foundation for Contemporary Art, http://www.almamalfoundation.org/index.php?action=events\&type=7\&artist=Mona Hatoum (accessed on 13 June 2012).

25 Hatoum interviewed by: Archer 1997, p. 27.
} 
nose were spilling over with wood. And that brought him to himself, rescued him only moments before the overpowering presence of the wood, its aroma, was about to suffocate him. He shook himself, slid down off the logs, and tottered away as if on wooden legs. Days later he was still completely fuddled by the intense olfactory experience, and whenever the memory of it rose up too powerfully within him he would mutter imploringly, over and over, "wood, wood." 26

The smell of the soap in Present Tense can similarly produce an embodied response in the viewer. Present Tense is Hatoum's only olfactory artwork, and Hatoum has never explicitly said anything about the effect of smells on viewers. However, in an interview in 1997, after the installation of Present Tense, Hatoum explained the importance of experiencing her artworks through the senses:

For me, the embodiment of an artwork is within the physical realm; the body is the axis of our perception, so how can art afford not [to] take that as a starting point? We relate to the world through our senses. You first experience an artwork physically. I like the work to operate on both sensual and intellectual levels. Meanings, connotations and associations come after the initial physical experience as your imagination, intellect, psyche are fired off by what you've seen. ${ }^{27}$

For Hatoum, a bodily experience of her work through the senses is essential as, again in her own words, this experience 'activate[s] a psychological and emotional response.' ${ }^{28}$ Although most artworks primarily address the viewer's sight in a direct way, the other senses - touch, hearing, smell and taste - can also play a role in engaging with artworks. ${ }^{29}$ Hatoum has also used sound in a couple of artworks to elicit emotional responses from the viewer, for instance in Home (1999) and Current Disturbance (1996).

In Present Tense, the smell of the Nablus soap pulls a viewer towards the work. As the material is a traditional Palestinian product, the smell can also evoke emotional responses to the work in Palestinians. Laura U. Marks has argued that smells activate emotions, and that individuals retain olfactory

\footnotetext{
26 Süskind 1985 , p. 17 .

27 Hatoum interviewed by: Archer 1997, p. 8.

28 Hatoum interviewed by: Antoni 2002, p. 123 .

29 For more information on the role of the non-visual senses in artworks, see: Art, History, and the Senses 2010.
} 
memories longer than visual or auditory memories. They can evoke personal and nostalgic memories of, for instance, grandmother's pie or mother's perfume. ${ }^{30}$ Hatoum has indicated that Palestinian visitors of the exhibition immediately recognized the material and the smell. ${ }^{31}$ It is, however, difficult to determine which thoughts, memories, emotions or ideas the smell actually triggered in the viewers. Perhaps the smell recalled childhood experiences, or possibly - as a symbol of the Palestinian identity - functioned as a reminder of the Nakba ${ }^{32}$, connecting it to the current Palestinian situation. Marks also points out that, for exiles, senses such as smell, taste and touch can be a reminder of the homeland, and especially a reminder of their separation from it. ${ }^{33}$ For the viewer's of Present Tense in 1996, the spread of the smell of the soap throughout the gallery in occupied East Jerusalem - for Palestinians an emotionally charged place - may not only have activated memories, but may also have intensified a longing for the homeland that was taken from them. This longing may have been accompanied by a feeling of sadness, because the homeland, as they knew it, no longer existed. The integration of the map of the Oslo Accords must have only enhanced that feeling, as it shows fragmented Palestinian territories. Hatoum activated the senses of Palestinian viewers with the scent of this work, which, along with the map of the Oslo Accords, may have caused a reliving of personal and cultural memories of Palestinian history and the loss of homeland.

The meaning of the smell of Nablus soap is, however, partially culturally determined. ${ }^{34}$ The smell of olive oil soap will only evoke memories in Palestinians, and only in those Palestinians who grew up with the smell. Viewers without a Palestinian background are likely not to be familiar with the specific scent. For these viewers, the smell of the soap perhaps only carries connotations of cleaning, and will conjure completely different thoughts, memories or emotions. The use of soap as a medium can also evoke a completely different reaction. An Israeli artist, for instance, asked Hatoum, after a lecture at the alWasiti Art Centre in East Jerusalem, if she was not aware that soap was connected with the Holocaust. During World War II, soap in the concentration

$30 \quad$ Marks 2000, p. 205.

31 Hatoum interviewed by: Archer 1997, p. 27.

32 Nakba is an Arabic term for catastrophe and refers to the events that took place in Palestine during and after 1948. Almost 80 percent of the Palestinians became refugees when, during the war, the state of Israel was established. For the Palestinians, this war was a 'catastrophe' as people were dispersed and their communal life was ended with violence, see: Abu-Lughod and Sa'di 2007, p. 3.

33 Marks 2000, pp. 231-32.

34 Classen 1993, pp. 1-11. 
camps was manufactured from the human fat of the camp's victims. ${ }^{35}$ Hatoum said about this reaction: 'This couldn't have been further from my thoughts.' ${ }^{36}$ Thus, viewers' reactions to the smell of the soap, or to the soap itself, can be very diverse, and the intensity of the reaction may also differ from viewer to viewer. But whatever responses viewers might have, the smell of the soap will provoke a physical sensation and set up an interplay between the viewer and the sculpture.

\section{Minimalism and Material}

Although the smell of the soap causes a physical reaction in the viewer, Hatoum also aimed to provoke a bodily experience of the work in the viewer through the use of the artistic language of Minimal Art. The majority of Minimalists wanted to create a physical relationship between the artwork and the viewer. Hatoum's placement of the blocks of soap in a grid on the floor is, however, especially reminiscent of the floor pieces by Minimal artist Carl Andre. For 144 Magnesium Square (1969), for example, Andre placed 144 plates of magnesium in a square flat on the floor (Fig. 1.5). The magnesium plates are unprocessed in part because Andre, like other Minimalists, aimed to make works that were not the expression of the artist's emotions. To achieve this, Andre used prefabricated industrial materials, which he did not carve or model. Andre left the materials intact, and in 144 Magnesium Square simply placed the plates next to each other to create a square. As none of the magnesium plates has been given more importance than another within the serial structure, there is no internal hierarchy in the work. 144 Magnesium Square does not refer to anything outside the work, but only to its own structure and the materials. For Andre the material was essential. He aimed for a direct and sensual engagement of the viewer with the work's physical and tactile qualities, such as the material's solidity, weight, and color, which a viewer could experience literally by touching the material or by walking on the work. ${ }^{37}$

The sculpture Present Tense is not a work of Minimal art, but Hatoum employs the minimalist language to set up a relation between artwork and viewer. Before discussing Hatoum's use of the minimalist language in Present Tense, this contribution expands on her ideas on a physical interaction between viewers and her artworks in general, as it provides a better understanding of how

\footnotetext{
35 Persekian 2013, s.p.

36 Hatoum interviewed by: Archer 1997, p. 27.

$37 \quad$ Gieskes 2006, p. 18.
} 


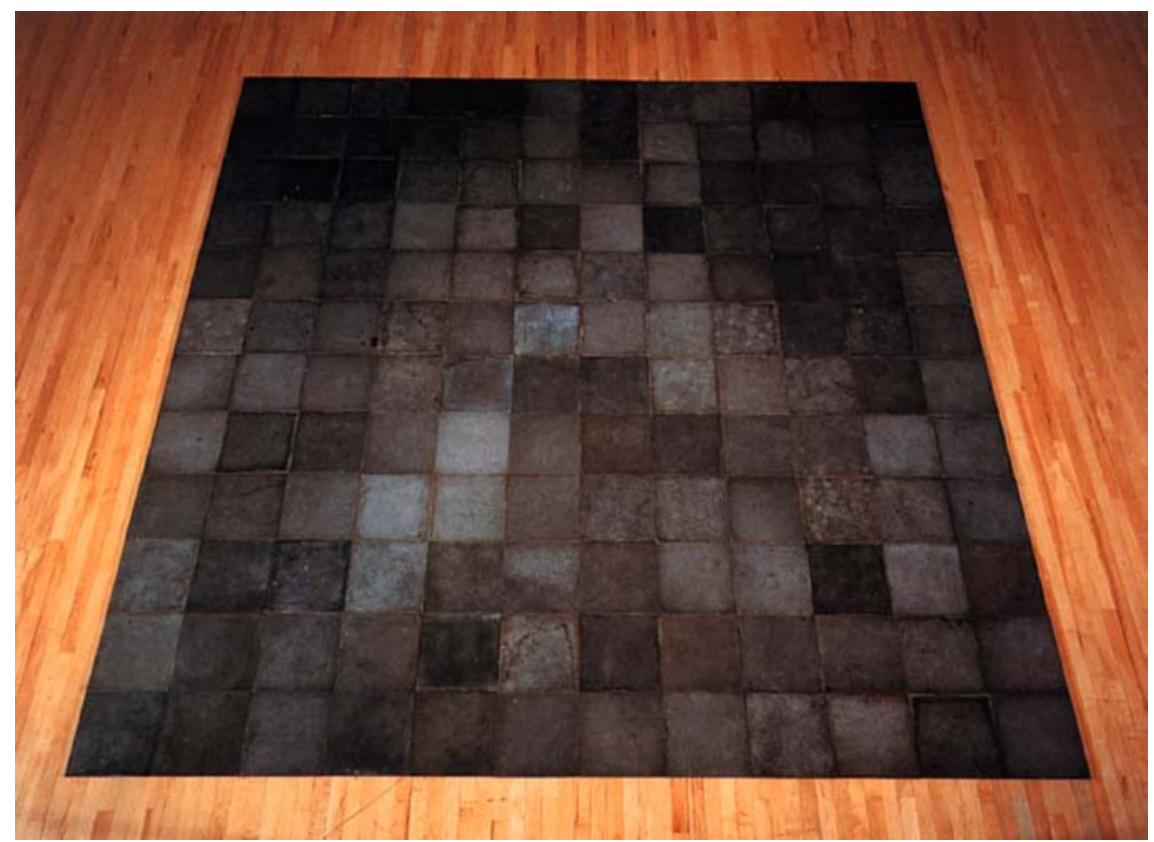

FIGURE 1.5 Carl Andre, 144 Magnesium Square, 1969, magnesium, $1 \times 365.8 \times 365.8 \mathrm{~cm}$, London: Tate Collection. (C) TATE, LONDON 2013, (C) CARL ANDRE, 144 MAGNESIUM SQUARE, 1969, C/O PICTORIGHT AMSTERDAM.

important this relationship has been for her since the late 1980s. Hatoum's early work in the 1980 s consisted of performances and video art, in which she often explicitly referred to events in the Middle East. After a few years, Hatoum felt that these works were too didactic, and she switched to installation art and sculptures. This switch in mediums also entailed a switch in her approach to the viewer, as she has explained: 'What changed is that instead of me delivering a message to the audience through my actions as a performer, I decided to set up situations where viewers could experience for themselves feelings of danger, threat, instability and uncertainty through the physical interaction with the work.' ${ }^{38}$

The first of Hatoum's works to establish a physical relationship between the viewer and the work was the installation The Light at the End (1989) (Fig. 1.6). Originally made for the Showroom, a gallery in East London, Hatoum placed six vertical electric heating elements in a steel frame in the corner of a room. The walls of the gallery were painted the color of dried blood and the room was

38 Hatoum quoted in: Masters 2008, s.p. 


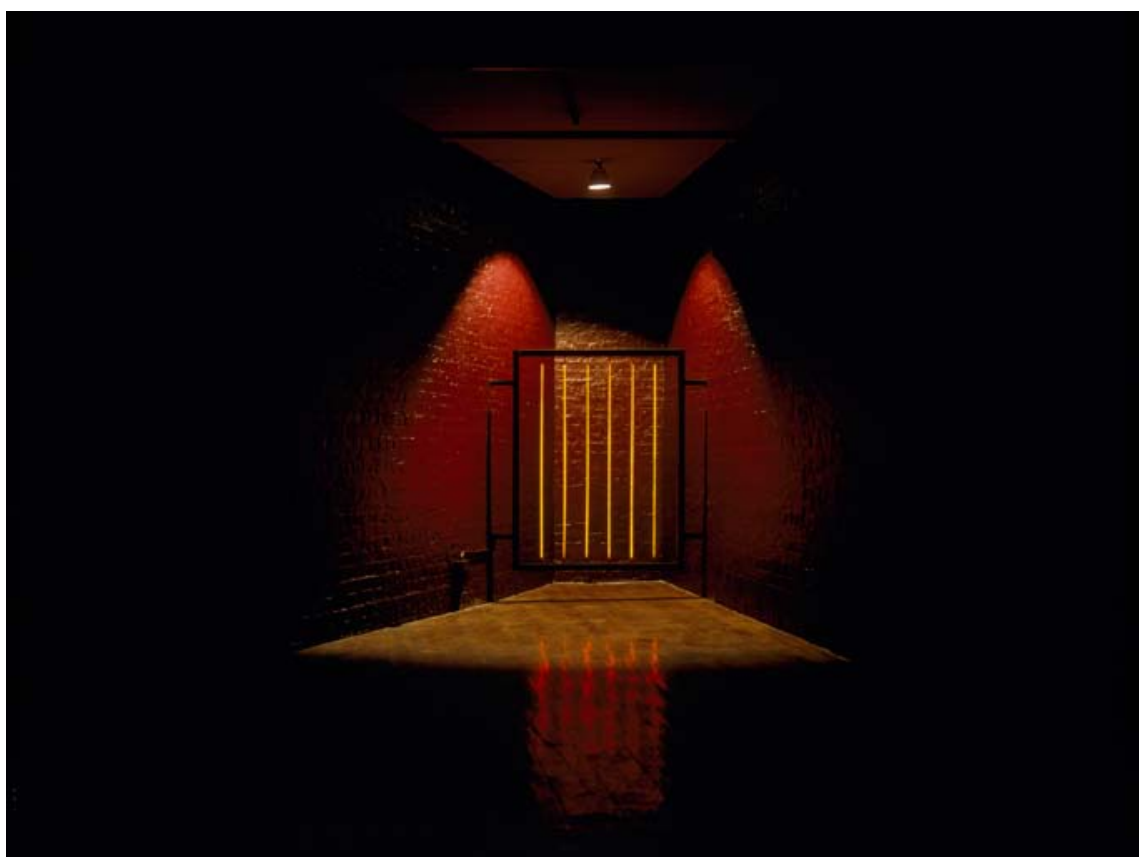

FIGURE 1.6

Mona Hatoum, The Light at the End, 1989, Angle iron frame, six electric heating elements, $166 \times 162.5 \times 5 \mathrm{~cm}$. PHOTO: EDWARD WOODMAN. COURTESY WHITE CUBE.

completely dark. ${ }^{39}$ Standing at a distance, the viewer was attracted by the beauty of the six red lines, but when approaching the work, the heat - another bodily sensation - became uncomfortable and at a certain point even threatening. As Hatoum states: 'The associations with imprisonment, torture and pain were suggested by the physical aspect of the work and the phenomenology of the materials used'. ${ }^{40}$ Hatoum established a physical relationship between the viewer and the work, so that through her work the viewer might experience feelings of threat, danger and fear.

The Light at the End and Present Tense both make use of a sensory experience to pull the viewer towards the work and arouse strong associative emotional responses. For both works, Hatoum used the minimalist aesthetic language. Hatoum started to use the minimalist language in 1989, when the physical interaction between viewer and artwork became important to her.

39 According to Brett, the room was even darker than it appears on the photographs, see: Brett 1997, p. 60.

40 Hatoum interviewed by: Archer 1997, p. 17. 
She has stated: 'I liked the minimal aesthetic because of the economy of form and the emphasis on the material reality of the work. At the time, it felt important to use the language of minimalism but also to fill it with signs that refer to the world outside, as opposed to keeping it non-referential.41

Although in this comment, Hatoum does not specifically refer to minimalists' preoccupation with the viewer's physical encounter with an artwork, Hatoum's appropriation of the minimalist aesthetic language in Present Tense contributes to a phenomenological experience and understanding of the work. As it is beyond the reach of this contribution to delve into the minimalists' theories on the viewer's bodily engagement, the following will be restricted to Andre's floor pieces, such as 144 Magnesium Square, which is similar to Present Tense on several levels. In his book The Sculptural Imagination. Figurative, Modernist, Minimalist, Alex Potts describes how a viewer's engagement with Andre's floor pieces differs from an interaction with a traditional sculpture. Andre's 144 Magnesium Square has no frontal view from which the sculpture is to be seen, so there is no fixed viewpoint. According to Potts, this lack of a singular viewpoint 'forces one to engage with the work at a kinaesthetic as well as purely visual level'. ${ }^{42}$ The work can be viewed from all sides, even from above. ${ }^{43}$ The viewer is invited to walk around, and even on, the work to experience the sculpture and its material.

As previously stated, for Andre, a direct engagement of the viewer with the physical and tactile qualities of his work is essential. He has written: '[...] [T]he tendency of my work is to engage the participant in a more physical, tactile experience. ${ }^{44}$ Although the viewer can have a tactile experience of the material used by Andre by walking on the work and touching the plates, they cannot experience the weight of the material, as they are not allowed to pick up the plates. According to Potts, this tactile experience of the work can only be experienced by the viewer through 'imaginative identification.45 The viewer has to imagine how the artist laid down the plates and feels the substance and mass

41 Hatoum quoted in: Masters, 2008, s.p.

42 Potts 2000, p. 313.

43 Potts also states that a complex dynamic arises between the encounter of the verticality of the viewer's body and the horizontality of the work, as it creates a tension between the two. The effect of this tension is an increased awareness of one's verticality and the horizontality of the floor piece, see: Potts 2000, p. 320.

44 Andre quoted in: Gieskes 20o6, p. 76.

45 Potts 2000, p. 321. According to Potts, viewers are never allowed to touch the plates of Andre's work. Potts seems to rest his statement on a leaflet that was handed out at an exhibition on Andre's sculptures in 1996 at the Museum of Art in Oxford, which stated that viewers should not touch the works. This seems inconsistent with Andre's ideas on 
of the material. Potts states that Andre was also fascinated by this internalized tactile experience before realizing the actual piece, when the artist laid down the work in his mind. As Andre claimed:

I do not visualize works and I do not draw works and the only sense I have running through my mind of the work is almost a physical lifting of it. I can almost feel the weight of it and something running through my mind either has the right weight or it doesn't. ${ }^{46}$

According to Potts, the viewer can share the artist's internalized tactile experience. Walking around and on the work, the viewer can imagine how the artist had a tactile experience with the material, just as a viewer can imagine how a sculptor carved a figure out of wood or marble, or molded clay. ${ }^{47}$

A viewer engaging with Hatoum's work Present Tense might have a similar tactile and bodily experience as a viewer of Andre's work. Similarly to a viewer's engagement with Andre's floor sculpture, the viewer can walk around Hatoum's sculpture Present Tense to experience the work from different perspectives. Although the viewer cannot walk on the work, nor touch its material, the viewer can also have an internalized tactile experience with the soap. The viewer can imagine touching the material and feeling its substance, or can imagine how Hatoum pressed the beads into the soap. Together with the smell of the soap, this internalized touching of the material enhances the engagement of the viewer with the work, and perhaps also the emotional response of Palestinian viewers. By drawing a political map on the soap, Hatoum relates the soap to a political reality, and establishes a sensual as well as political engagement with the work for the viewer. This is different from Carl Andre's work, which does not explicitly refer to politics, even if the artist's political convictions in part determined the structure, materials, and form of his work. ${ }^{48}$ Within the politically charged context of Jerusalem, Hatoum uses the minimalist aesthetic language to emphasize the material and to set up a relationship between the viewer and the artwork, to make the viewer aware of their own body in relation to the site and to engage the viewer on a physical level with the political content of the work.

the viewer's participation with his works. It is likely, however, that the leaflet is the result of the museum's policy on conservation.

46 Andre quoted in: Potts 2000, p. 321.

47 Potts 2000, p. 321.

48 See Gieskes 2006, pp. 14-97. 


\section{Reinstallations of Present Tense}

As Present Tense was shown at, and made explicitly for, an exhibition in Jerusalem, the context of the city affects the work. Hatoum, however, reinstalled the work several times, for instance for her solo exhibition Present Tense: Mona Hatoum at the Parasol Unit, Foundation for Contemporary Art in London in 2008; at the group exhibition Disorientation II: The Rise and Fall of Arab Cities at Abu Dhabi Art in 2009-2010; and at a solo exhibition at Arter in Istanbul in 2012. In 2013, as already mentioned, the original work from 1996 was acquired by the Tate, and is now part of their permanent collection. ${ }^{49}$ When a site-specific work is moved to another place, the replacement affects the meaning and interpretation of the work. ${ }^{50}$ The site at which the work is made informs it, and is therefore part of the interpretation. With a relocation, the relationship between work and site is broken, and as a result the meaning of the work shifts.

Present Tense is no longer exhibited in the highly charged political context of Jerusalem, but the work never entirely loses its political content. That is partly due to Hatoum's use of the political map of the Oslo Accords, but also because visitors to the later exhibitions are given information about the background of the sculpture. The meaning of Present Tense now differs from exhibition to exhibition. In the context of the exhibition in Istanbul, the meaning of Present Tense was framed in relation to other works in Hatoum's oeuvre, with their recurring themes of war, conflict and borders. Within the group exhibition Disorientation II: The Rise and Fall of Arab Cities, Hatoum's sculpture obtained its meaning through the context of the subject of the exhibition. This exhibition showed the work of Arab artists who examined issues of conflicts, war and displacement in their work after the utopian vision of the pan-Arab unity failed in the $1970 .^{51}$

The question may arise, however, whether the reinstallation and conservation of Present Tense is desirable, as the sculpture loses a major part of its

49 As Present Tense has not been on display yet at the Tate, it is unknown in what context it will be exhibited and what it will mean for the notion of 'site-specificity'.

50 Kaye 2000, pp. 1-2.

51 'Disorientation II: The Rise and Fall of Arab Cities', Sharjah Art Foundation, http://www. sharjahart.org/exhibitions-events/past-events-2009/november/disorientation-ii-therise-and-fall-of-arab-citie (accessed on 5 December 2012). During this exhibition, there was also a performance by Jack Persekian, director and curator of Hatoum's 1996 exhibition in Jerusalem, and Tarek Atoui, in which they react on Present Tense. It is beyond the scope of this article to discuss the performance, but for an excerpt, see: Nablus Soap excerpt, YouTube video, 6:29 min., March 10, 2011, http://www.youtube.com/watch?v= Fa22rgbggle (accessed on 5 December 2012). 
social, cultural and political implications in these new and different contexts. For instance, the present author saw the sculpture at Hatoum's solo exhibition in Istanbul in 2012, along with 29 other artworks by Hatoum from the $1990 \mathrm{~s}$ until the present years. Although, as said before, Present Tense does not lose its political content entirely in new contexts, the work does lose its 'sharp edges'. This is probably enhanced by the fact that the soap was already 16 years old: the smell was gone! In a video from 2011 that is made available on YouTube, Hatoum says that she is also remaking the work, because of the brown stains on the soap: 'At the time [of the making of Present Tense], we didn't think about conservation very much, so it is all drying out, shrinking, and going brown. So now what we are doing with the fresh soap is that we are covering it with liquitex to seal the moisture in, so that hopefully it will stay like this.' ${ }^{52}$ Because of the liquitex, the material will stay intact, but the work will no longer have its characteristic smell.

Apparently, the shift in the meaning of Present Tense due to a recontextualization and the loss of smell are not problems for Hatoum. What is also striking is that these reinstallations, the conservation, and remaking of the sculpture disregard an important dimension of the original work: the implications of the transient nature of soap, which in its dissolving process also dissolved the borders within the work. The reinstallations as well as the new version of the work thus show that the recontextualization and conservation of Present Tense has consequences for the meaning of the work, which was originally linked to a particular site, to Jerusalem.

\section{Bibliography}

Abu-Lughod, Lila, and Ahmad H. Sa'di, 'Introduction:The Claims of Memory', in: Nakba. Palestine, 1948, and the claims of memory, ed. by Ahmad H. Sa'di and Lila Abu-Lughod, New York etc. 2007, pp. 1-24.

'Al-Ma'hal Historical Background', Al-Ma'hal. Foundation for Contemporary Art, http:// www.almamalfoundation.org/aboutus.php (accessed on 28 June 2012).

Ankori, Gannit, Palestinian Art, London 2006.

Antoni, Janine, 'Mona Hatoum interviewed by Janine Antoni', in: Mona Hatoum, exhib. cat., ed. by Christina Zelich, pp. 117-31, Salamanca etc.: Centro de Arte de Salamanca

$5^{2} \quad$ Hatoum quoted in: TateShots: Mona Hatoum, studio visit, YouTube video, 4:15 min., posted by Tate, September 29, 2011, http://www.youtube.com/watch?v=Xs3Dzydsku8 (accessed on 25 June 2012). The final destination of this new version of Present Tense is at the moment of writing unknown to this author. 
and Centro Galego de Arte 2002. Originally published in Bomb Magazine, no. 63 (Spring 1998).

Archer, Michael, 'Interview. Michael Archer in conversation with Mona Hatoum', in: Mona Hatoum, London 1997, pp. 8-30.

Art, History, and the Senses: 1830 to the Present, ed. by Patrizia di Bello and Gabriel Koureas, Farnham etc. 2010.

Black, Jeremy, Maps and Politics, London 1997.

Brett, Guy, 'Itinerary', in: Mona Hatoum, London 1997, pp. 34-87.

Classen, Constance, Worlds of Sense. Exploring the Senses in History and across Cultures, London and New York 1993.

'Disorientation II: The Rise and Fall of Arab Cities'. Sharjah Art Foundation, http://www. sharjahart.org/exhibitions-events/past-events-2009/november/disorientation-iithe-rise-and-fall-of-arab-citie (accessed on 5 December 2012).

Fischback, Michael R. 'Oslo Agreements', in: Encyclopedia of the Palestinians, ed. by Philip Mattar, Chicago etc. 2000[a], pp. 284-85.

—_. 'Jerusalem', in: Encyclopedia of the Palestinians, ed. by Philip Mattar, Chicago etc. 2000 [b], pp. $208-15$.

Foucault, Michel, Discipline and Punish. The Birth of the Prison, transl. by Alan Sheridan, New York 1979. Original publication: Surveiller et punir. Naissance de la prison, Paris 1975.

Gieskes, Mette, The Politics of System in the Art of CarlAndre, Sol LeWitt, and Vito Acconci, 1959-1975, Ph.D. diss., University of Texas at Austin 2006.

Kaye, Nick, Site-Specific Art. Performance, Place and Documentation, New York and London 2000.

Makdisi, Saree, Palestine Inside Out. An Everyday Occupation, New York [etc.] 2008.

Mansoor, Jaleh, 'Mona Hatoum's Biopolitics of Abstraction', October 133 (summer 2010), pp. 49-74.

Marks, Laura U., The Skin of the Film. Intercultural Cinema, Embodiment, and the Senses, Durham and London 2000.

Masters, H.G., 'Mona Hatoum: Domestic Insecurities', ArtAsiaPacific Magazine 2008, http://artasiapacific.com/Magazine/59/DomesticInsecuritiesMonaHatoum (accessed on 28 June 2012).

'Mona Hatoum'. Al-Ma'hal. Foundation for Contemporary Art, http://www.almamalfoundation.org/index.php?action=events\&type $=7 \&$ artist=Mona Hatoum $($ accessed on 13 June 2012).

Mona Hatoum: Mappings, Vimeo video, 24:03 min., posted by Serpentine Gallery, 2011, http://vimeo.com/24541176 (accessed on 7 November 2012).

Montefiore, Simon Sebag, Jerusalem. The Biography, London 2011.

Morgan, Jessica, 'The Poetics of Uncovering. Mona Hatoum In and Out of Perspective', in: Mona Hatoum, exhib. cat., Chicago: Museum of Contemporary Art 1997, pp. 1-23. 
'Nablus' olive oil soap: a Palestinian tradition lives on'. Institute for Middle East Understanding (IMEU), http://imeu.net/news/articleoo8132.shtml (accessed on 7 September 2012).

Nablus Soap excerpt, YouTube video, 6:29 min., 10 March 2011, http://www.youtube.com/ watch?v=Fa22rgbggle (accessed on 5 December 2012).

Persekian, Jack, 'Mona Hatoum: Present Tense', ArtAsiaPacific Magazine 2013, http:// www.artasiapacific.com/Magazine/84/PresentTensemonahatoum (accessed on 10 July 2013).

Pieters, Din, 'Mona Hatoum', in: Mona Hatoum, exhib. cat., ed. by E. van Duyn, Amsterdam: De Appel 1997, s.p.

Potts, Alex, The Sculptural Imagination. Figurative, Modernist, Minimalist, New Haven and London 2000.

Süskind, Patrick, Perfume. The Story of a Murderer, transl. by John E. Woods, New York 1985. Original publication: Das Parfum. Die Geschichte eines Mörders, Zürich 1985, retrieved from: http://ebookbrowse.com/patrick-suskind-perfume-the-story-of-amurderer-pdf-d162932379 (accessed on 4 September 2012).

TateShots: Mona Hatoum, studio visit, YouTube video, 4:15 min., posted by Tate, 29 September 2011, http://www.youtube.com/watch?v=Xs3Dzydsku8 (accessed on 25 June 2012).

Zimmer, Nina, 'Ephiphanies of the Everyday Materiality and Meaning in Mona Hatoum's Work', in: Mona Hatoum, exhib. cat., ed. by Christoph Heinrich, Hamburger Kunsthalle/ Kunstmuseum Bonn/ Magasin 3 Stockholm Konsthall, Ostfildern-Ruit 2004, pp. 66-72 